\title{
Can occur hormesis in guinea grass using glyphosate?
}

\author{
Gianmarco J. T. Gallardo ${ }^{a}$, Allan L. Bacha ${ }^{\mathrm{a} \oplus}$, Willians C. Carrega ${ }^{\mathrm{a} \oplus}$, Alcebiades R. S. Joséb®, Pedro L. da C. A. Alves ${ }^{\mathrm{a} \odot}$

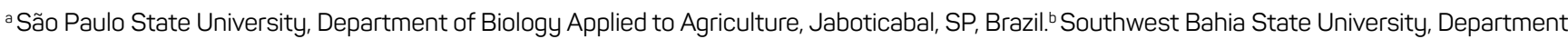 \\ of Phytotechnics and Zootechnics, Vitória da Conquista, BA, Brazil.
}

\begin{abstract}
Background: Recent studies have demonstrated an increase in plant growth due to the application of low doses of glyphosate, which is part of the phenomenon known as hormesis. Objective: The present study aimed to evaluate the effects of glyphosate doses on the physiological and morphological parameters of Panicum maximum cv. Mombaça. Methods: The experiment was carried out in a greenhouse for 49 days after the application of glyphosate, in pots arranged in a completely randomized design, with four replications. The treatments consisted of ten doses of glyphosate $(0 ; 3.78 ; 8.10 ; 16.64 ; 33.48 ; 67.7 ; 135 ; 270 ; 540$ and 1,080 g
\end{abstract}

\begin{abstract}
a.e. $\mathrm{ha}^{-1}$ ). Evaluations of growth, gas exchange, leaf temperature and plants' intoxication were carried out. The data were subjected to ANOVA and when significant, regression analysis was performed using the models for dose-response curves. Results: The physiological parameters, as well as the growth, were positively affected by the subdoses of glyphosate, with higher values than the control. The leaf temperature increased progressively according to the increase in doses. Conclusion: Subdoses of 3.78 to $270 \mathrm{~g}$ a.e. ha ${ }^{-1}$ of glyphosate promoted an increase in plant's growth and physiological parameters.
\end{abstract}

Keywords: dose-response; gas exchange; Megathyrsus maximus; Panicum maximum; subdose.

Journal Information:

ISSN - 2675-9462

Website: http://awsjournal.org

Journal of the Brazilian Weed Science Society

How to cite: Gallardo GJT, Bacha AL, Carrega WC, José ARS, Alves PLCA. Can occur hormesis in guinea grass using glyphosate? Adv Weed Sci. 2021;39:00064

https://doi.org/10.51694/AduWeedSci/2021;39:00019

\section{Approved by:}

Editor in Chief: Anderson Luis Nunes

Associate Editor: Arthur Martins Barroso

Conflict of Interest: The authors declare that there is no conflict of interest regarding the publication of this manuscript.

Received: November 19, 2020

Approved: October 25, 2021

* Corresponding author: <allan_lb@hotmail.com>

\section{(c) (4)}

This is an open-access article distributed under the terms of the

Creative Commons Attribution License, which permits unrestricted use, distribution, and reproduction in any medium, provided that the original author and source are credited.

Copyright: 2021

\section{Introduction}

Glyphosate is the most widely used herbicide in the world, due to several aspects related to the reduction of labor costs and its mode of action. Thus, as it has a broad spectrum of control and is highly effective, it is the main option for weed control in various agricultural production systems (Duke, Powles, 2008; Velini et al., 2009).

However, recent studies have shown that low doses of this herbicide can act stimulating the growth of several plant species (Velini et al., 2008; Cedergreen, Olesen, 2010; Carvalho et al., 2013; Pereira et al., 2013; Carbonari et al., 2014; Nascentes et al., 2018), possibly due to changes in the shikimic acid pathway (Velini et al., 2008), which is responsible for approximately $20 \%$ of the carbon assimilated by plants (Haslam, 1993). Such biphasic dose-response effect, in which low doses cause a stimulatory effect, followed by high doses causing a toxic effect, is known as hormesis (Calabrese, Baldwin, 2002).

Treating a crop with subdoses of a herbicide for a desirable phenotypic change can be valuable (Duke et al., 2006); for example, when glyphosate is applied in subdoses to stimulate the accumulation of sucrose and prevent flowering in sugar cane (Velini et al., 2009; Araldi, 2010). In a different way, it is also worth mentioning the work of Pereira et al. (2013), that when applying reduced doses (from 3.6 to $36.0 \mathrm{~g}$ a.e. ha ${ }^{-1}$ ) of glyphosate in eucalyptus seedlings, reported increases of up to $22 \%$ in the dry matter of the crop. Doses within this range were also responsible for the increase of up to $20 \%$ in the dry matter of non-resistant soybean, compared to the control (Velini et al., 2008). For forage species (Brachiaria brizantha), Nascentes et al. (2015) observed a growth $31.8 \%$ greater than plants without application, for the dose of $10.5 \mathrm{~g}$ a.e. $\mathrm{ha}^{-1}$. In spite of this, studies that aim to increase the vegetative mass of Panicum maximum for grazing, in response to a hormetic effect, are incipient in the literature.

The guinea grass ( $P$. maximum syn. Megathyrsus maximus) is considered an important grass in pasture areas in several regions of Brazil, being one of the first forage species introduced in the country (Souza, 1999). Thus, the knowledge of their physiological and morphological characteristics is essential for the establishment of adequate management (Rodrigues, Reis, 1995). Thus, the study of the hormetic effect caused by low doses of glyphosate can be a viable alternative for the management of this species, aiming to an increase in plant growth and consequently production of green mass.

In addition to cultures varying in their responses due to the application of different glyphosate doses, as mentioned above, Belz and Duke (2014) pointed out 
that other factors can also interfere in the occurrence, or not, of the hormetic effect. They are: plant development stage (Carvalho et al., 2013), the final evaluation point (Cedergreen et al., 2009), environmental conditions at the time and after products' application (Belz, Cedergreen, 2010) and the clone or cultivar chosen (McDonald et al., 2001). Thus, studies are needed to understand how plant species respond to these variables not only to better understand this biological phenomenon, but also to obtain greater assertiveness in management aiming at increasing $P$. maximum green mass for pasture with the use of this herbicide.

Thus, according to what has been reported, we hypothesize that $P$. maximum, as observed for other species, including grasses, may respond positively to glyphosate subdoses, showing an increase in its growth. Thus, the present study aimed to evaluate the effects of increasing doses of glyphosate on physiological and morphological aspects of Panicum maximum cv. Mombaça, in order to identify doses that cause a stimulatory effect on the plants.

\section{Materials and Methods}

The experiment was carried out in greenhouse conditions, in the municipality of Vitória da ConquistaBA, with geographical coordinates of: $14^{\circ} 53^{\prime} 32.2^{\prime \prime}$, $40^{\circ} 48^{\prime} 23.9^{\prime \prime} \mathrm{W}$ and altitude of $923 \mathrm{~m}$. The study was conducted for 49 days after the application (DAA) of the treatments, when an average temperature of $22.7^{\circ} \mathrm{C}$ (maximum of $28.7^{\circ} \mathrm{C}$ and minimum of $17.9{ }^{\circ} \mathrm{C}$ ) and relative humidity of $67.5 \%$ were registered.

The plant species Panicum maximum (syn. Megathyrsus maximus) cv. Mombaça (guinea grass), acquired from Sementes Rancharia ${ }^{\circledR}$, located in the municipality of Rancharia-SP, was used. Sowing was carried out in polypropylene trays, previously filled with agricultural substrate.

At 20 days after sowing, three seedlings were transplanted to pots with a capacity of $2 \mathrm{~L}$, containing soil removed from the arable layer of a soil classified as RedYellow Alic Oxisol. Pre-transplant fertilization was carried out with amounts equivalent to $48 \mathrm{~kg}$ of $\mathrm{KCl} \mathrm{ha}{ }^{-1}, 40 \mathrm{~kg}$ of simple superphosphate ha- ${ }^{-1}$ and $100 \mathrm{~kg}$ of urea ha ${ }^{-1}$.

Irrigation was performed with deionized water, with 200 $\mathrm{mL}$ applied per plot, per day, distributed in one application in the morning and another in the afternoon, until 25 DAA of the treatments. After this period, the amount of water per pot was doubled.

The experimental treatments consisted of ten doses of glyphosate $\left(\right.$ Crucial $\left.^{\circledR}\right)$ : $0 ; 3.78 ; 8.10 ; 16.64 ; 33.48 ; 67.7 ; 135$; 270; 540 and 1,080 g a.e. ha ${ }^{-1}$. A completely randomized design was used, with four replications.

The herbicide's application was carried out when the plants had two to three leaves fully expanded, with height less than $10 \mathrm{~cm}$ (40 days after sowing). The application was made using a $\mathrm{CO}_{2}$-pressurized backpack sprayer (2 $\mathrm{kgf} \mathrm{cm} \mathrm{cm}^{-2}$ ), coupled to a bar containing four 110-02 flat jet tips, spaced at $0.5 \mathrm{~m}$, regulated for a tank volume of $220 \mathrm{~L} \mathrm{ha}^{-1}$. At the time of application, the soil was moist, and the temperature and relative humidity were $28^{\circ} \mathrm{C}$ and $56.5 \%$, respectively.

Twenty four hours after herbicide's application, the rate of net $\mathrm{CO}_{2}$ assimilation, stomatal conductance, transpiration rate, intercellular $\mathrm{CO}_{2}$ concentration and leaf temperature were determined using an infrared gas analyzer (IRGA, mod. LCpro-SD, ADC BioScientific ${ }^{\circledR}$ ). The evaluations were conducted on the second fully expanded leaf, in the basipetal direction, with a minimum length of $2.5 \mathrm{~cm}$. For this purpose, a chamber for dicotyledonous leaves adapted to monocotyledons was used, with a dichroic light source in the upper part of the chamber. The working conditions were: $400 \mu \mathrm{mol} \mathrm{CO} \mathrm{mol}^{-1}$; $19 \mathrm{mmol} \mathrm{H}_{2} \mathrm{O} \mathrm{mol}^{-1}$; air temperature was set at $25^{\circ} \mathrm{C}$ and the photosynthetically active photon flow of $1200 \mu \mathrm{mol} \mathrm{m}^{-2} \mathrm{~s}^{-1}$.

In addition, at 7, 14, 21, 28, 35 and 42 DAA of glyphosate, the number of tillers per plant was also evaluated, as well as the degree of intoxication, using the visual scale proposed by Sbcpd (1995), in which 0\% corresponded to the absence of injuries and $100 \%$ to the plants' death.

At the end of the experimental period (49 DAA), the guinea grass plants were cut close to the soil, and their leaves were detached to the leaf area determination (mod. LI-3100, LiCor ${ }^{\circledR}$, USA). Then, leaves and culms were placed into a forced air circulation oven, at a temperature of $70^{\circ} \mathrm{C}$, for 120 hours, to determine the dry matter mass, after weighing on a precision scale.

The data obtained were subjected to ANOVA by the F test (AgroEstat ${ }^{\circledR}$ software) and when significant, regression analysis was performed using the models for dose-response curves $\left(\right.$ Origin $^{\circledR}$ 8.5, OriginLab ${ }^{\circledR}$ ), using the equation proposed by Brain and Cousens (1988).

\section{Results and Discussion}

Analyzing the gas exchange parameters evaluated 24 hours after glyphosate's application, it was found that the net $\mathrm{CO}_{2}$ assimilation rate $(A)$ obtained a constant increase, from the dose of 3.78 to $270 \mathrm{~g}$ a.e. ha ${ }^{-1}$, with a sharp drop in subsequent doses (Figure 1a). On this occasion, the greatest increase in $\mathrm{CO}_{2}$ assimilation was obtained by plants that received a dose of $270 \mathrm{~g}$ a.e. $\mathrm{ha}^{-1}$, reaching values approximately $92 \%$ higher than the control without application (Figure 1a).

For the transpiration rate $(E)$ of guinea grass plants, the response pattern was the same as that observed for $A$, in which doses from 3.78 to $270 \mathrm{~g}$ a.e. ha ${ }^{-1}$ provided a constant increase in this characteristic, followed by a sharp drop caused by the two highest doses (Figure 1b). The spraying of $270 \mathrm{~g}$ a.e. ha ${ }^{-1}$ of glyphosate was the one that provided the greatest increase in the plants' transpiration rate, with an increase of $114 \%$ compared to the control (Figure $1 \mathrm{~b}$ ).

As for stomatal conductance $\left(g_{s}\right)$, it was noted that the three lowest doses did not cause an increase in the values 
of this variable, equaling the control (Figure 1c). Again, the dose of $270 \mathrm{~g}$ a.e. ha ${ }^{-1}$ of glyphosate provided the highest value of $g_{s}$, being $56 \%$ higher than the control, possibly because it is a variable directly related to the transpiration rate (Figure $1 c$ ).

As for the intercellular carbon concentration $\left(C_{i}\right)$, the response pattern was the opposite of the net $\mathrm{CO}_{2}$ assimilation rate, in which there was a continuous drop in values, up to the dose of $270 \mathrm{~g}$ a.e. $\mathrm{ha}^{-1}$, followed by a recovery in the two highest doses (540 and $1080 \mathrm{~g}$ a.e. ha ${ }^{-1}$ ) (Figure 1d). These results are directly related to the use of carbon in the photosynthetic process, being inversely proportional. Thus, the carbon molecules present in the leaf mesophyll were used in the $\mathrm{CO}_{2}$ assimilation process, in which the plants that obtained the highest $A$ also obtained the lowest $C_{\mathrm{i}}$ (Figures $1 \mathrm{a}$ and $1 \mathrm{~d}$ ).
Regarding leaf temperature, measured at the same time as gas exchange, there was a continuous increase directly related to the increase in glyphosate doses (Figure 2).

It was possible to observe that at 7 days after application (DAA), plants intoxication started from the dose of $135 \mathrm{~g}$ a.e. ha ${ }^{-1}$, causing $35 \%$ of toxicity compared to the control and reaching up to $47 \%$ in the highest dose $\left(1,080\right.$ g a.e. ha $\left.{ }^{-1}\right)$ (Figure 3). At $14 \mathrm{DAA}$, it was noted that from the dose of $67.7 \mathrm{~g}$ a.e. $\mathrm{ha}^{-1}$ there was intoxication in the treated plants, which remained until 28 DAA, always with values below $11 \%$. In general, the highest intoxication scores were observed at 14 DAA. At 21 DAA there was a reduction of symptoms in plants, which led to a total recovery of intoxication levels at $42 \mathrm{DAA}$, except for the highest dose of glyphosate $\left(1,080 \mathrm{~g}\right.$ a.e. $\left.\mathrm{ha}^{-1}\right)$, which maintained $8.61 \%$ grades at the end of the experimental period (Figure 3 ).
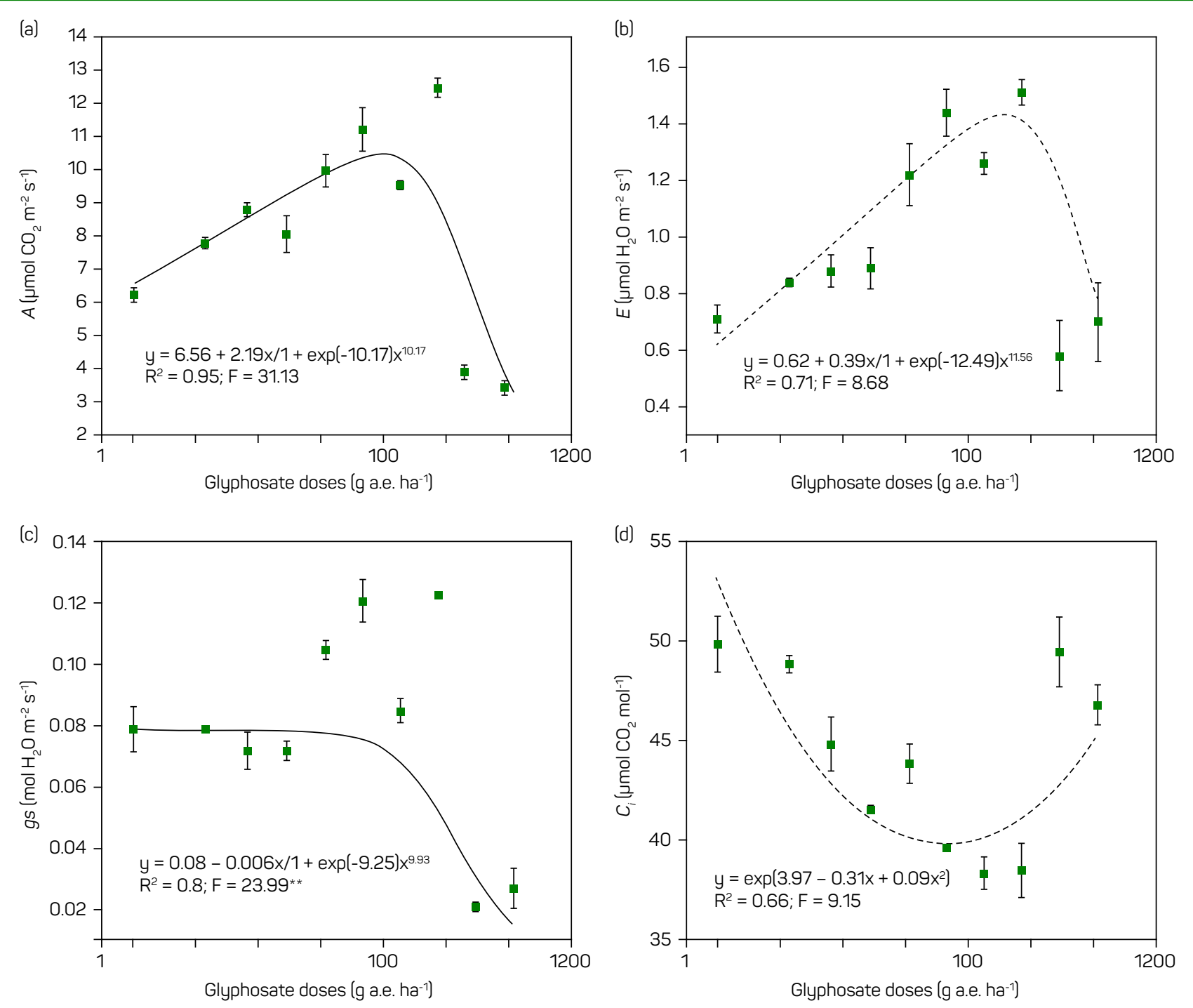

Figure 1 - Net $\mathrm{CO}_{2}$ assimilation rate (a), transpiration rate (b), stomatal conductance (c) and internal carbon concentration (d) of Panicum maximum plants 24 hours after application of increasing doses $(0 ; 3.78 ; 8,10 ; 16.64 ; 33.48 ; 67.7 ; 135 ; 270 ; 540$ and $1080 \mathrm{~g}$ a.e. ha-1) of glyphosate. The bars indicate the standard error of mean $(N=4)$. 
For the dose that caused the greatest stimulatory effect on guinea grass (270 g a.e. ha-1), the highest intoxication scores was observed at $14 \mathrm{DAA}$, with values of $35 \%$. After this period, there was a progressive decrease in symptoms, until their absence, at 42 DAA (Figure 3).

As for the tillering of P. maximum plants, at 7 DAA, a reduction of $75 \%$ in the number of tillers was observed, compared to the control, when the plants were exposed to the dose of 1,080 g a.e. ha- ${ }^{-1}$ of glyphosate (Figure 4). At 14 DAA, the dose of $135 \mathrm{~g}$ a.e. ha ${ }^{-1}$ provided a $38 \%$ increase in the number of tillers, compared to the control (Figure 4). From 21 DAA, it was observed that the highest dose $(1,080$ g a.e. $\mathrm{ha}^{-1}$ ) of glyphosate stimulated tillering, a fact that was maintained throughout the evaluations, with $116 \%$ increments at 28 DAA, $117 \%$ at 35 DAA and $56 \%$ at 42 DAA (Figure 4). Despite this, this increase in the number of tillers did not increase any growth variable at the end of the experimental period (Figures 5, 6a and 6b).

Regarding leaf area, an average increase of $24 \%$ was observed for the doses from 3.78 to $540 \mathrm{~g}$ a.e. $\mathrm{ha}^{-1}$, when compared to the control without application (Figure 5). Specificallyfor the dose of 540 ga.e.ha ${ }^{-1}$,itisworthmentioning that although the plants in this treatment obtained a larger leaf area than the control, this increase did not result in a greater production of dry matter of leaves (Figure 6b), which suggests the formation of thinner and lighter leaves.

On the other hand, the highest dose of the product caused a reduction in the leaf area of $27 \%$ compared to the control (Figure 5), even whit this treatment obtaining the largest amount of tillers (Figure 4), which shows the toxic effect of this dose to the plant growth.

For the dry matter of culms (DMC), it was possible to observe that the lowest dose ( $3.78 \mathrm{~g}$ a.e. $\mathrm{ha}^{-1}$ ) of glyphosate

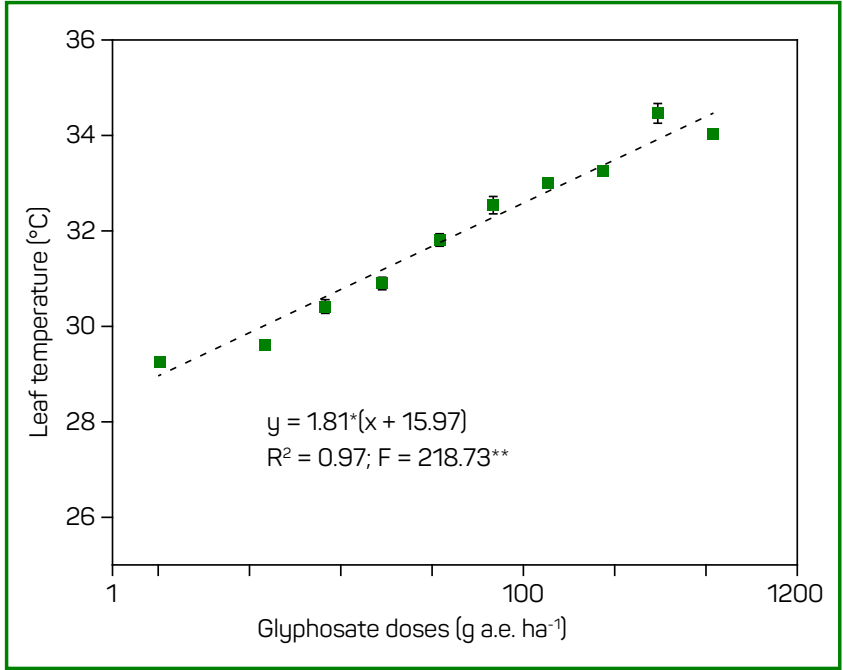

Figure 2 - Leaf temperature $\left({ }^{\circ} \mathrm{C}\right.$ ) of Panicum maximum plants 24 hours after application of increasing doses 10 ; 3.78; 8.10 ; 16.64; 33.48; 67.7; 135; 270; 540 and 1080 g a.e. ha-1) of glyphosate. The bars indicate the standard error of mean $(N=4)$. was the one that provided the greatest growth of guinea grass culms, being approximately $21 \%$ higher than the control (Figure 6a). In the following doses, there was a gradual decrease in the values of DMC as the doses of glyphosate increased. Thus, as well as occurred for the net $\mathrm{CO}_{2}$ assimilation rate (Figure 1a), the doses of 540 and 1,080 g a.e. ha ${ }^{-1}$ were the only ones that caused a deleterious effect on plant growth.

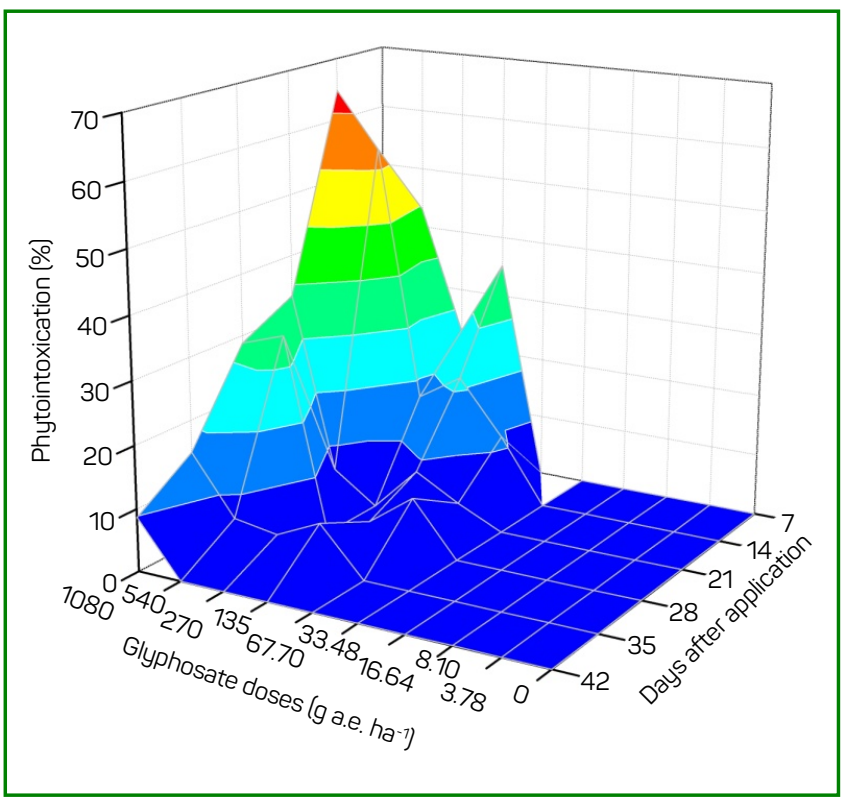

Figure 3 - Phytointoxication percentage (SBCPD, 1995) of Ponicum moximum plants, evaluated at 7, 14, 21, 28, 35 and 42 days after application (DAA) of increasing doses of glyphosate.

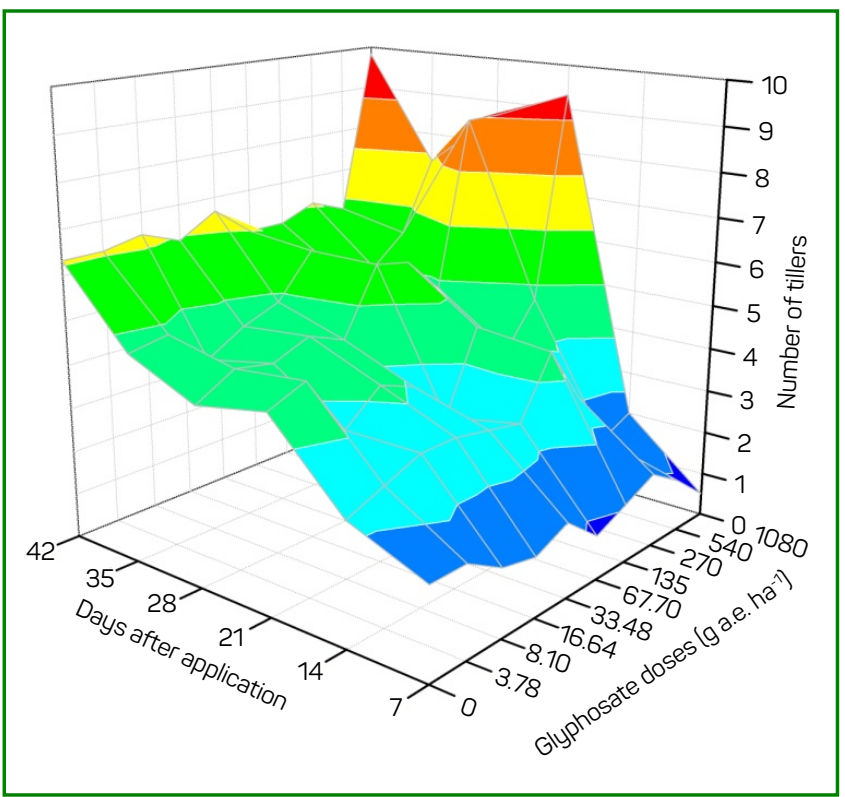

Figure 4 - Number of tillers of Panicum maximum plants, evaluated at 7, 14, 21, 28, 35 and 42 days after application (DAA) of increasing doses of glyphosate. 


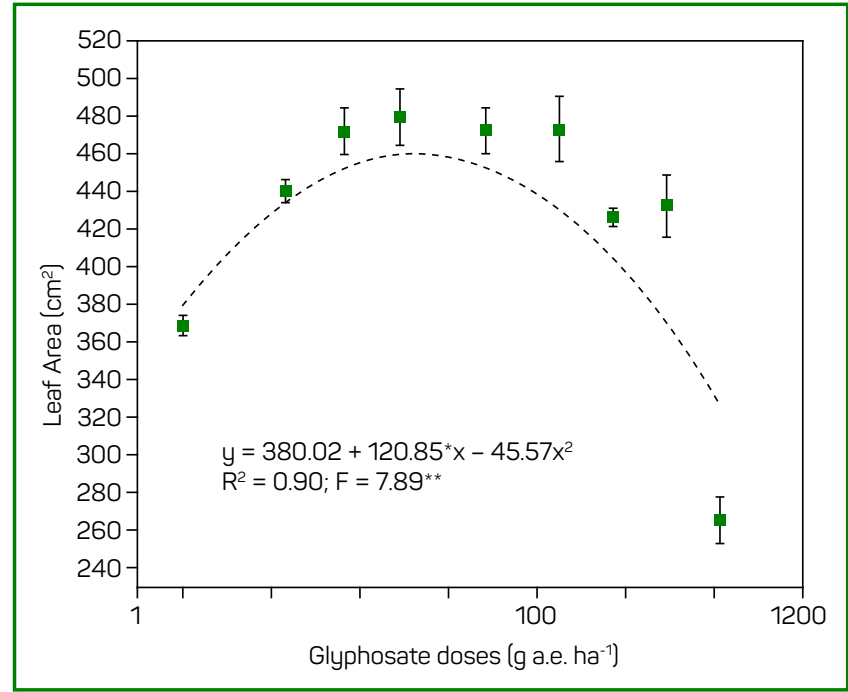

Figure 5 - Leaf area $\left(\mathrm{cm}^{2}\right)$ of Ponicum maximum plants at 49 days after application of increasing doses $(0 ; 3.78 ; 8.10 ; 16.64$ 33.48; 67.7; 135; 270; 540 and 1080 g a.e. ha-1) of glyphosate. The bars indicate the standard error of mean $(N=4)$.

Regarding the dry matter of leaves (DML), there was a progressive growth in response to the increase in doses up to $16.64 \mathrm{~g}$ a.e. $\mathrm{ha}^{-1}$, when the plants obtained DML $26.3 \%$ higher than the control. From this dose on, again a gradual decrease in values was noticed according to the increase in the herbicide doses (Figure 6b). It is important to note that, as with DMC, doses of up to 270 g a.e. ha ${ }^{-1}$ did not decrease the growth of $P$. maximum plants, when compared to control (Figures $6 \mathrm{a}$ and $6 \mathrm{~b}$ ).

The increase in dry matter of guinea grass observed in the present study, caused by the application of low doses of glyphosate, is part of the phenomenon defined as hormesis. This term consists of a dose-response with a biphasic effect, caused by a stimulus due to the application of a chemical product that is toxic in high concentrations (Calabrese, Baldwin, 2002; Belz, Duke, 2014).

Glyphosate is the most used product with the intention of promoting the hormetic effect in plants (Brito et al., 2018). Thus, in recent years, several studies have been conducted in order to understand this phenomenon, both in dicotyledonous species [Eucalyptus urograndis (Pereira et al., 2013), Coffea arabica (Carvalho et al., 2013) and Glycine max (Velini et al., 2008)] as in monocot species [Brachiaria brizantha (Nascentes et al., 2015); Brachiaria decumbens (Moraes et al., 2020); Saccharum officinarum (Silva et al., 2009); Zea mays (Wagner et al., 2003)].

This increase in plant growth in response to subdoses of glyphosate has not yet been fully clarified, but it is likely to be related to changes in the shikimic acid pathway (Velini et al., 2008; Cedergreen, Olesen, 2010). Velini et al. (2008) observed that glyphosate-resistant soybean showed no changes in growth and concentration of shikimic acid when exposed to the herbicide. Conversely, soybean
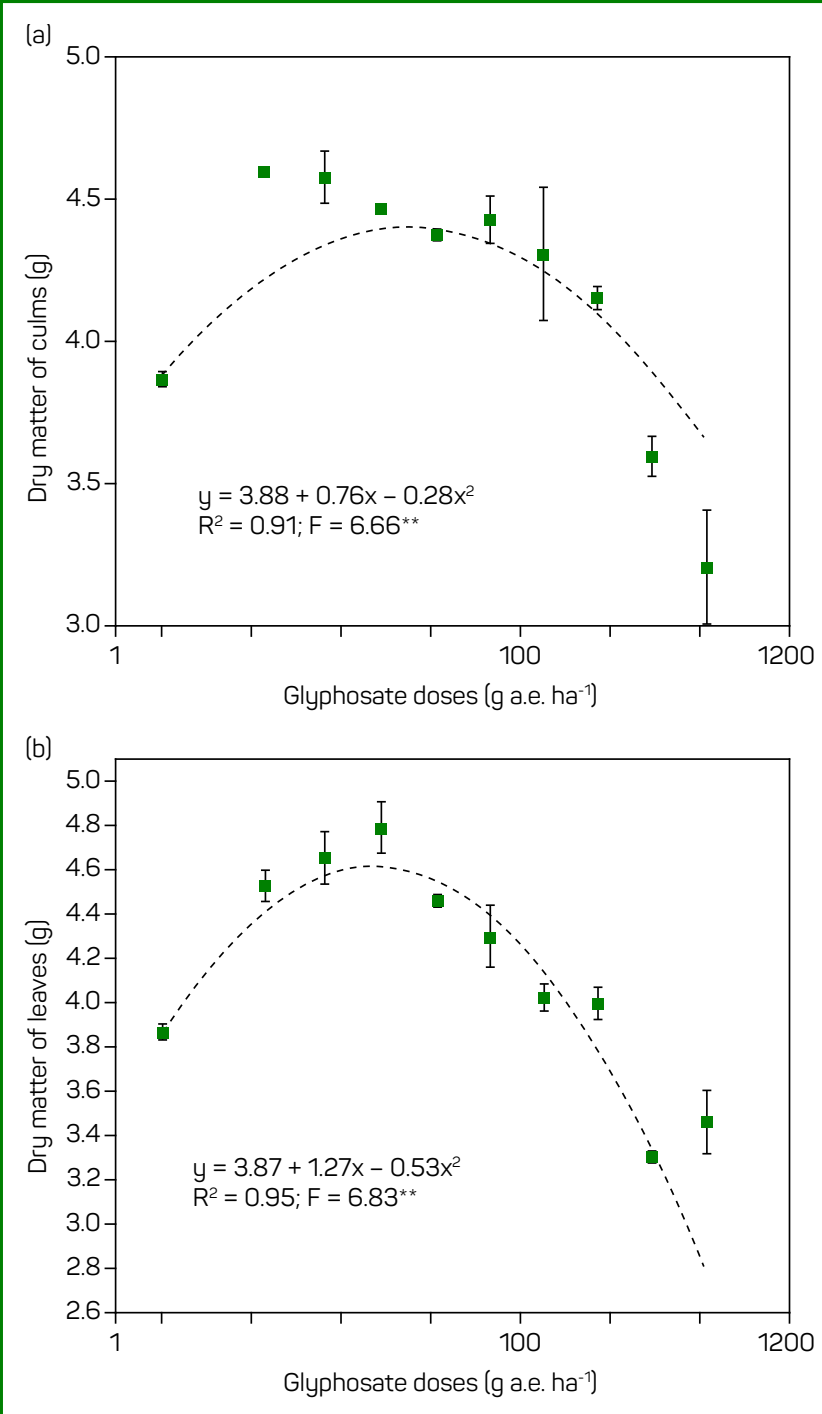

Figure 6 - Dry matter of culms (a) and dry matter of leaves (b) of Ponicum moximum plants at 49 days after application of increasing doses $(0 ; 3.78 ; 8.10 ; 16.64 ; 33.48 ; 67,7,135,270$, 540 and $1080 \mathrm{~g}$ a.e. ha-1) of glyphosate. The bars indicate the standard error of mean $(N=4)$.

plants susceptible to glyphosate had a mass increase of approximately $20 \%$ compared to the control, as well as an increase in the concentration of this substance.

Once at the site of action, glyphosate inhibits the enzyme EPSPs (5-enolpyruvylchiquime-3-phosphate synthase), which is responsible for catalyzing the reaction of phosphoenolpyruvate and chiquimate-3-phosphate, forming the phosphated enolpyruvatochiquite-3phosphate compound. Enolpyrivulchicamate-3-phosphate is a precursor to chorisic acid, which will produce the amino acids phenylalanine, tyrosine and tryptophan (Fedtke, Duke, 2005). Thus, a reduction in the synthesis of these compounds, will result in less production of essential amino acids in the route of shikimic acid, being that approximately 
$20 \%$ of the carbon fixed by the plant is destined to this route (Haslam, 1993), altering, with this, the synthesis of proteins, vitamins, alkaloids and also several important phenolic compounds, such as flavonoids and phytohormone auxin (Velini et al., 2009).

In addition, low doses of this herbicide inhibit lignin synthesis, making cell walls more elastic for a longer period and resulting in greater longitudinal growth (Duke et al., 2006), but not justifying the increase in dry matter observed in present experiment (Figure 6). Thus, an increase in the $\mathrm{CO}_{2}$ assimilation rate is also one of the main factors in the increase in the production of vegetable mass (Figure 1 ).

In the present study, an increase in the net $\mathrm{CO}_{2}$ assimilation rate $(A)$ of $92 \%$ was verified for the $270 \mathrm{~g}$ a.e. ha ${ }^{-1}$ dose. Barley plants, on the other hand, obtained $A$ approximately $20 \%$ higher than the control, when they were sprayed with $45 \mathrm{~g}$ a.e. ha ${ }^{-1}$ of glyphosate (Cedergreen, Olesen, 2010). In a similar way, Nascentes et al. (2018) observed an increase of about $60 \%$ in sugarcane plants with doses of up to $36 \mathrm{~g}$ a.e. ha ${ }^{-1}$.

Cedergreen and Olesen (2010) observed that the increase in photosynthetic rates of barley treated with low doses of glyphosate remained for up to 7 consecutive days. The authors attributed the greater growth of plants to the increase in the efficiency of carbon assimilation, and not to the greater efficiency in the use of light. Thus, this increase in photosynthetic activity is related to the increase in rubisco activity, in the rate of use of triose phosphate and/ or in the regeneration of RuBP (Cedergreen, Olesen, 2010).

Regarding the leaf temperature, it was observed that there was a gradual increase as the doses of glyphosate also increased (Figure 2). We hypothesize that the increase in leaf temperature is related to the greater metabolic activity in the cells of this tissue, caused by the herbicide. Thus, at doses from 3.78 to $270 \mathrm{~g}$ a.e. ha ${ }^{-1}$, the result of these reactions was observed in the increase in mass (Figure 6), while at doses considered toxic, the metabolic activity was directed to the plant detoxification through the processes of inactivation or compartmentalization of the herbicide (Cole, 1994; Reddy et al., 2008). In this sense, it is worth mentioning that through measurements on respiration rates, Cedergreen and Olesen (2010) found greater metabolic activity in barley plants one day after exposure to low doses of glyphosate. The authors observed that the higher the dose, the greater the respiratory activity on the first day, which tended to gradually decrease on subsequent days.

Thus, the management of pastures with low doses of this chemical can become a viable alternative in order to increase the vegetal mass to be consumed by the animals, and also considering that the phytointoxication evaluations for the doses that stimulated the plants growth were not higher than mild or null (Figure 3). Nascentes et al. (2015) observed an increase of $21 \%$ in the dry matter of the aerial part of Brachiaria brizantha at 30 days after the application of $12.62 \mathrm{~g}$ a.e. ha ${ }^{-1}$ of glyphosate. In the present study, an average increase of $21 \%$ was found for DMC and $26.3 \%$ for DML, at 49 DAA. Such increment may favor the increase in the stocking rate of animals in the grazing area, which is directly influenced by the amount of vegetal mass offered (Barioni, Ferreira, 2007).

Despite this, Belz et al. (2011) highlighted that the use of herbicides in order to increase crop productivity should be widely studied, since the plant's development stage itself can influence the occurrence, or not, of the hormetic effect. In this sense, Cedergreen (2008) reported not having observed productivity gains when applying glyphosate to barley in a two-leaf stage. However, when the herbicide was applied at a grain filling stage, Cedergreen et al. (2009) found an increase in production of 12 to $15 \%$. Additionally, it is important to note that the occurrence of hormesis is also dependent on the correct association of the plant's development with the dose used. Velini et al. (2008), working with Commelina benghalensis in the four-leaf stage, had to apply a dose five times higher than that used in the two-leaf stage, so that the greatest stimulus to plant growth could be observed. In addition to these, other factors can also influence the occurrence of hormesis, as previously mentioned, namely: environmental conditions at the time and after product application (Belz, Cedergreen, 2010), clone or cultivar chosen (McDonald et al., 2001), and the final evaluation point (Cedergreen et al., 2009), that is, the period after exposure to the product that it will be evaluated. Thus, more studies must be developed in this sense in order to clarify the possible variations that may occur in field situations.

\section{Conclusion}

We concluded that the subdoses of 3.78 to 270 g a.e. ha ${ }^{-1}$ of glyphosate promoted an increase in growth and in the physiological parameters of Panicum maximum cv. Mombaça. The application of glyphosate in doses of $540 \mathrm{~g}$ a.e. ha ${ }^{-1}$ or higher, caused a deleterious effect on plant growth.

\section{Authors' contributions}

PLCAA, and ARSJ: conceptualization, methodology development and project administration. GJTG: conducted the experiment. ALB, WCC, and GJTG: performed formal analyses and wrote the original manuscript. All authors collaborated in the process of revising and editing the final version of this manuscript.

\section{Acknowledgements}

The authors are grateful to the Weed Sciences Laboratory (LAPDA) of Universidade Estadual Paulista (Unesp) Jaboticabal in partnership with Universidade Estadual do Sudoeste da Bahia (UESB) for the research project development, and also to the National Council for Scientific and Technological Development (CNPq). 
Araldi R. [Flowering in sugarcane]. Cienc Rural. 2010;40(3):674-702 Portuguese. Available from: https://doi.org/10.1590/S0103-847820 10005000033

Barioni LG, Ferreira AC. [Monitoring of forage mass and height for stocking rate adjustments in an agricultural farm in the Cerrado region] Planaltina: Embrapa Cerrados; 2007. Portuguese.

Belz RG, Cedergreen N. Parthenin hormesis in plants depends on growth conditions. Environ Exp Bot. 2010;69(3):293-301. Available from: https://doi.org/10.1016/j.envexpbot.2010.04.010

Belz RG, Cedergreen N, Duke SO. Hericide hormesis: can it be useful in crop production? Weed Res. 2011;51(4):321-32. Available from: https://doi.org/10.1111/j.1365-3180.2011.00862.x

Belz RG, Duke SO. Herbicides and plant hormesis. Pest Manag Sci. 2014;70(5):698-707. Available from: https://doi.org/10.1002/ps.3726

Brain $\mathrm{P}$, Cousens $\mathrm{R}$. An equation to describe dose responses where there is stimulation of growth at low doses. Weed Res. 1988;29(2):93-6. Available from: https://doi.org/10.1111/j.13653180.1989.tb00845.x

Brito IP, Tropaldi L, Carbonari CA, Velini ED. Hormetic effects of glyphosate on plants. Pest Manag Sci. 2018;74(5):1064-70. Available from: https://doi.org/10.1002/ps.4523

Calabrese EJ, Baldwin LA. Defining hormesis. Hum Exp Toxicol. 2002;21(2):91-7. Available from: https://doi.org/10.1191/ 0960327102ht217oa

Carbonari CA, Gomes GLGC, Velini ED, Machado RF, Simões OS, Macedo GC. Glyphosate effects on sugarcane metabolism and growth. Am J Plant Sci. 2014;5(24):3585-93. Available from: https://doi. org/10.4236/ajps.2014.524374

Carvalho LB, Alves PLCA, Duke SO. Hormesis with glyphosate depends on coffee growth stage. An Acad Bras Cienc. 2013;85(2):813-22. Available from: https://doi.org/10.1590/S000137652013005000027

Cedergreen N, Felby C, Porter JR, Streibig JC. Chemical stress can increase crop yield. Field Crop Res. 2009;114(1):54-7. Available from: https://doi.org/10.1016/j.fcr.2009.07.003

Cedergreen N. Herbicides can stimulate plant growth. Weed Res. 2008;48(5): 429-38. Available from: https://doi.org/10.1111/j.13653180.2008.00646.x

Cedergreen N, Olesen CF. Can glyphosate stimulate phosynthesis? Pestic Biochem Phys. 2010;96(3):140-8. Available from: https://doi.org/10.1016/j.pestbp.2009.11.002

Cole DJ. Detoxification and activation of agrochemicals in plants. Pestic Sci. 1994;42(3):209-22. Available from: https://doi.org/10.1002/ ps. 2780420309

Duke SO, Powles SB. Glyphosate: a once-in-a-century herbicide. Pest Manag Sci. 2008;64(4):319-25. Available from: https://doi. org/10.1002/ps.1518
Duke SO, Cedergreen N, Velini ED, Belz R. Hormesis: is it an important factor in herbicide use and allelopathy? Outlooks Pest Manag. 2006;17(1):29-33.

Fedtke C, Duke SO. Herbicides. In: Hock B, Elstner EF, editors. Plant toxicology. New York: Marcel Dekker; 2005. p. 247-330.

Haslam E. Shikimic acid: metabolism and metabolites. Chinchester: John Wiley; 1993.

McDonald $L$, Morgan T, Jackson P. The effect of ripeners on the CCS of 47 sugarcane varieties in the burdekin. In: Proceedings of the 2001 Conference of the Australian Society of Sugar Cane Technologists; Mackay, Australia. Queensland: Australian Society of Sugar Cane Technologists; 2001. p. 102-8.

Moraes CP, Brito IPFS, Tropaldi L, Carbonari CA, Velini ED. Hormetic effect of glyphosate on Urochloo decumbens plants. J Environ Sci Heal B. 2020;55(4):376-81. Available from: https://doi.org/10.1080/ 03601234.2019 .1705114

Nascentes RF, Carbonari CA, Simões PS, Brunelli MC, Velini ED, Duke SO. Low doses of glyphosate enhance growth, $\mathrm{CO}_{2}$ assimilation, stomatal conductance and transpiration in sugarcane and eucalyptus. Pest Manag Sci. 2018;74(5):1197-205. Available from: https://doi.org/10.1002/ps.4606

Nascentes RF, Fagan EB, Soares LH, Oliveira CB, Brunelli MC. [Glyphosate Hormesis in Brachiaria brizanto cv. Marandu]. Rev Centro Univ Patos de Minas. 2015;6:55-64. Portuguese

Pereira FCM, Nepomuceno MP, Pires RN, Parreira MC, Alves PLCA. Response of eucalyptus (E. urograndis) at different doses of glyphosate. J Agr Sci. 2013;5:66-74

Reddy KN, Rimando AM, Duke SO, Nandula VK. Aminomethylphosphonic acid accumulation in plant species treated with glyphosate. J Agr Food Chem. 2008;56(6):2125-30. Available from: https://doi. org/10.1021/jf072954f

Rodrigues LRA, Reis RA. [Basis for the establishment of Panicum weeds]. Proceedings of the $12^{\circ}$ Simpósio sobre Manejo da Pastagem; Piracicaba, Brasil. Piracicaba: Fundação de Estudos Agrários Luiz de Queiroz; 1995. p. 197-218. Portuguese.

Sociedade Brasileira da Ciência das Plantas Daninhas - Sbcpd. [Procedures for installing, evaluating and analyzing herbicide experiments]. Londrina: Sociedade Brasileira da Ciência das Plantas Daninhas, 1995. Portuguese

Silva MA, Aragão NC, Barbosa MA, Jeronimo EM, Carlin SD [Hormetic effect of glyphosate on the initial development of sugarcane]. Bragantia. 2009;68(4):973-8. Portuguese. Available from: https://doi.org/10.1590/S0006-87052009000400017

Souza FHD. Panicum moximum in Brazil. In: Loch DS, Ferguson JE, editors. Forage seed production, volume 2: tropical and subtropical species. New York: CABI; 1999. p. 363-70.

Velini ED, Duke SO, Trindade MLB, Meschede DK, Carbonari CA [Glyphosate action mode]. In: Velini ED, Meschede D, Carbonari CA Trindade MLB, editors. [Glyphosate]. Botucatu: Fundação de Estudos e Pesquisas Agrícolas e Florestais; 2009. p. 113-34. Portuguese. 
Velini ED, Alves E, Godoy MC, Meschede DK, Souza RT, Duke SO. Glyphosate at low doses can stimulate plant growth. Pest Manag Sci. 2008;64(4):489-96. Available from: https://doi. org/10.1002/ps.1562
Wagner R, Kogan M, Parada AM. Phytotoxic activity of root absorbed glyphosate in corn seedlings (Zeo mays L.). Weed Biol Manag. 2003;3(4):228-32. Available from: https://doi.org/10.1046/j.1444$6162.2003 .00110 . x$ 